\title{
The mineralizing fluid in the Piaba gold deposit, São Luís cratonic fragment (NW-Maranhão, Brazil) based on fluid inclusion studies in quartz veins O fluido mineralizador no depósito aurífero Piaba, Fragmento Cratônico São Luís (NW-Maranhão, Brasil), com base em estudos de inclusões fluidas em veios de quartzo

\author{
Saney C. F. de Freitas ${ }^{1 *}$, Evandro L. Klein ${ }^{1,2}$
}

\begin{abstract}
Piaba is the first gold mine to operate in the São Luís cratonic fragment, NW-Maranhăo, northern Brazil. The geological setting comprises chiefly metavolcano-sedimentary sequences (Aurizona Group) and subduction-related granitoids (Tromaí Intrusive Suite), formed in island arc between 2240 and $2150 \mathrm{Ma}$. Gold mineralization is hosted in a fine-grained granophyric granodiorite (Piaba Granophyre) and in a subvolcanic andesite of the Aurizona Group. The mineralized zone is confined within the limits of the Piaba fault (ENE-WSW-trending brittle-ductile shear zone) and consists of quartz veins and veinlets and accompanying hydrothermal haloes (chlorite + muscovite + carbonate + pyrite + chalcopyrite + gold) disposed in stockwork geometry. Petrographic, microthermometric and microRaman spectroscopic studies of quartz have defined two- and three-phase aqueous-carbonic fluid inclusions produced by heterogeneous trapping during phase separation, in addition to late aqueous fluids. The mineralizing solution is an aqueous-carbonic fluid composed of $\mathrm{CO}_{2}(5-24 \mathrm{~mol} \%), \mathrm{H}_{2} \mathrm{O}(74-93 \mathrm{~mol} \%), \mathrm{N}_{2}$ $(\leq 1 \mathrm{~mol} \%)$ and $\mathrm{CH} 4(\leq 1 \mathrm{~mol} \%)$. It presents low salinity $(5.5$ wt. $\%$ $\mathrm{NaCl}$ equivalent) and density of $\left.0.96-0.99 \mathrm{~g} / \mathrm{cm}^{3}\right)$. Ore deposition occurred at $267-302^{\circ} \mathrm{C}$ and $1.25-2.08$ kbars, corresponding to $4-7 \mathrm{~km}$ in depth, in agreement with the structural information. The P-T-X and reduced characteristics $\left(\log f_{\mathrm{O}_{2}}-31.3\right.$ to -34.3$)$ of the fluid, combined with host rock sulfidation, altogether indicate that gold has been transported as a sulfur complex and that ore deposition occurred in response to phase separation and lowering of the sulfur activity and $f \mathrm{O}_{2}$ during fluid-rock interaction.
\end{abstract}

KEYWORDS: fluid inclusions; gold; Säo Luís Craton; metallogeny; $\mathrm{CO}_{2}$.
RESUMO: $O$ depósito aurifero de Piaba tornou-se a primeira mina em operaçáa no fragmento cratônico São Luis, noroeste do Maranhão. Seu ambiente geológico compreende rochas metavulcanossedimentares do Grupo Aurizona e granitoides da Suite Tromaí, entre outras unidades menores, formadas em ambiente de arcos de ilhas entre 2240 e $2150 \mathrm{Ma}$, juntamente com outras unidades menores. A mineralização é caracterizada por uma trama stockwork de veios e vênulas de quartzo com seus halos de alteração (clorita + muscovita + carbonato + pirita + calcopirita e ouro) hospedada em um granodiorito granofírico fino (Granófiro Piaba) e em rocha subvulcânica andesitica do Grupo Aurizona. O corpo mineralizado é espacialmente limitado à zona de cisalhamento ENE-WSW rúptil-dúctil (Falha Piaba). Estudos petrográficos, microtermométricos e por espectroscopia microRaman no quartzo definiram inclusóes aquo-carbônicas bifásicas e trifásicas, produzidas por aprisionamento heterogêneo durante separação de fases, e fluidos aquosos tardios. A solução mineralizadora corresponde a um fluido aquo-carbônico composto por $\mathrm{CO}_{2}$ (5-24 mol\%, densidade de 0,96-0,99 g/ $\left.\mathrm{cm}^{3}\right), \mathrm{H}_{2} \mathrm{O}(74-93 \mathrm{~mol} \%)$, $\mathrm{N}_{2}$ ( 1 mol\%), $\mathrm{CH}_{4}(\leq 1 \mathrm{~mol} \%)$ e $5,5 \%$ em peso $\mathrm{NaCl}$ equivalente. O minério depositou a $267-302^{\circ} \mathrm{C}$ e 1,25-2,08 kbar, correspondendo a profundidades de 4 a $7 \mathrm{~km}$, em consonância com o regime estrutural. A composição e o intervalo de P-T do fuido mineralizador, combinados com o caráter redutor $\left(\log f_{\mathrm{O}_{2}}-31,3\right.$ a $\left.-34,3\right)$ e a sulfetaçáo da rocha hospedeira, sugerem que o ouro foi transportado como um complexo sulfetado. O minério foi depositado em consequência da separação de fase, redução da atividade de enxofre e da $\mathrm{fO}_{2}$ pela interação fluido-rocha.

PALAVRAS-CHAVE: inclusōes fluidas; ouro; Cráton São Luís; metalogênese; $\mathrm{CO}_{2}$.

${ }^{1}$ Federal University of Pará, Belém (PA),Brazil. E-mails: saney.freitas@vale.com, evandro.klein@cprm.gov.br ${ }^{2}$ Companhia de Pesquisa de Recursos Minerais - CPRM, Belém (PA), Brasil.

*Corresponding author

Manuscrito ID 26753. Recebido em: 28/04/2012. Aprovado em: 21/01/2013 


\section{INTRODUCTION}

The São Luís cratonic fragment, in the northern Brazil, contains important gold occurrences known since the $17^{\text {th }}$ century. Since then, these occurrences have been the locus of artisanal mining, in general limited to the secondary (alluvial and supergenic) exposures. More recently, systematic exploratory work developed by mining companies allowed the discovery of the Piaba deposit, among other eighteen showings and deposits, and the opening of the first industrial mine in the State of Maranhão. The Piaba deposit is located near the Aurizona village, in the municipality of Godofredo Viana (Fig. 1). Measured and indicated reserves total $78 \mathrm{Mt}$ grading $1.26 \mathrm{~g} / \mathrm{t}$, and inferred reserves total 15.2 Mt at $1.47 \mathrm{~g} / \mathrm{t}$ (Lunagold 2012).

There are a few genetic studies for some occurrences of the São Luís cratonic fragment, such as Caxias, Areal and Pedra de Fogo. In these cases, aspects of the hydrothermal alteration have been addressed and the mineralizing fluid has been investigated on the basis of fluid inclusions and stable isotope studies (Klein et al. 2005a and references therein). At Piaba, to date only the oxidized (supergenic) ore has been investigated (Souza 2001), but little is known about the Genesis of the primary ore. As such, this paper aims to contribute with the understanding of the mineralizing process at Piaba focusing on the physicochemical characteristics of the ore-bearing fluids through the study of fluid inclusions hosted in quartz veinlets. Although being of local interest, this work brings for the first time genetic information on the first gold mine of the São Luís cratonic fragment.

\section{GEOLOGICAL SETTING}

The study area is located in the northern portion of the São Luís cratonic fragment. In this area, rocks belonging to the Aurizona Group and Tromaí Intrusive Suite crop out (Fig. 1). The Aurizona Group holds the older rocks in the cratonic area $(2240 \pm 5 \mathrm{Ma}$, Klein \& Moura 2001). It consists of a metavolcano-sedimentary sequence composed of schists, acidic to basic metavolcanic rocks, phylite, quartzite and metachert (Pastana 1995; Klein et al. 2005b). Geochemical and isotopic data have led Klein et al. (2009) to interpret the sequence as related to island arc and/or back-arc basin. This sequence was intruded by granitoids of the Tromaí Intrusive Suite, which is mostly represented by tonalites, granodiorites and monzogranites. The juvenile granitoids have metaluminous to weakly peraluminous, low- to high-K calc-alkaline signature related to island arcs formed between $2168 \pm 4 \mathrm{Ma}$ and $2149 \pm 4 \mathrm{Ma}$ (Klein et al. 2005a, 2008a, 2008b).
Minor volcanic units are coeval with the Tromaí suite and comprise the tholeiitic basalts and calc-alkaline andesites of the Serra do Jacaré unit and calc-alkaline rhyolites and dacites of the Rio Diamante Formation. The units represent mature to continental arc sequences (Klein et al. 2009). Granitoids that crop out in the western sector of the São Luís cratonic fragment are related to the Tracuateua Intrusive Suite, which is formed by collision-type, peraluminous two-mica granites of $2080 \pm 2 \mathrm{Ma}$ to $2091 \pm 5 \mathrm{Ma}$ (Costa 2000, Palheta 2001). The youngest units of the São Luís cratonic fragment comprise the shoshonitic Negra Velha Granite, with age between 2076 and 2056 Ma (Klein et al. 2008b), and the dacites and tuffs of the Rosilha volcanic unit formed at about $2068 \mathrm{Ma}$ (Klein et al. 2009).

The São Luís cratonic fragment is considered to be the South-American portion of the West-African Craton, which is a major continental block formed in the Rhyacian period and that was relatively stable during the evolution of the Neoproterozoic orogens that surround this block (Klein \& Moura 2008). The evolution of this Rhyacian block probably involved an accretionary phase between 2240 and $2140 \mathrm{Ma}$, which is represented mainly by the Aurizona Group and the Tromaí Intrusive Suite, and by a collision phase at about $2100 \mathrm{Ma}$, represented by the peraluminous Tracuateua Suite. The Negra Velha and Rosilha units have been related to late- to post-orogenic events (Klein et al. 2008b, 2009 and references therein).

\section{Summary of the geology of the Piaba deposit}

\section{Host rocks}

The host rocks of the gold ore at Piaba belong to the metavolcano-sedimentary Aurizona Group, formed during the Rhyacian orogeny and subsequently affected by the Piaba fault in the same orogenic event (Pastana 1995, Klein et al. 2008a).

According to Mineração Aurizona (2000, unpublished internal report), in the deposit area the Aurizona Group is composed of graphite-bearing schist and metachert, tuffs, quartz-sericite-chlorite schist and mafic to ultramafic rocks. In addition, fine-grained granophyric rocks of tonalitic to granodioritic composition supposedly intruded the supracrustal rocks of the Aurizona Group (Fig. 2). These granophyric rocks have been generically named Piaba Granophyre by Klein et al. (2008a), who have also determined the emplacement age at $2214 \pm 3 \mathrm{Ma}$ (single-zircon $\mathrm{Pb}$ evaporation). More recently, however, Mach \& Clarke (2008, unpublished internal report) have not mentioned the granophyric rocks and have interpreted the host rocks as andesites and basalts. 


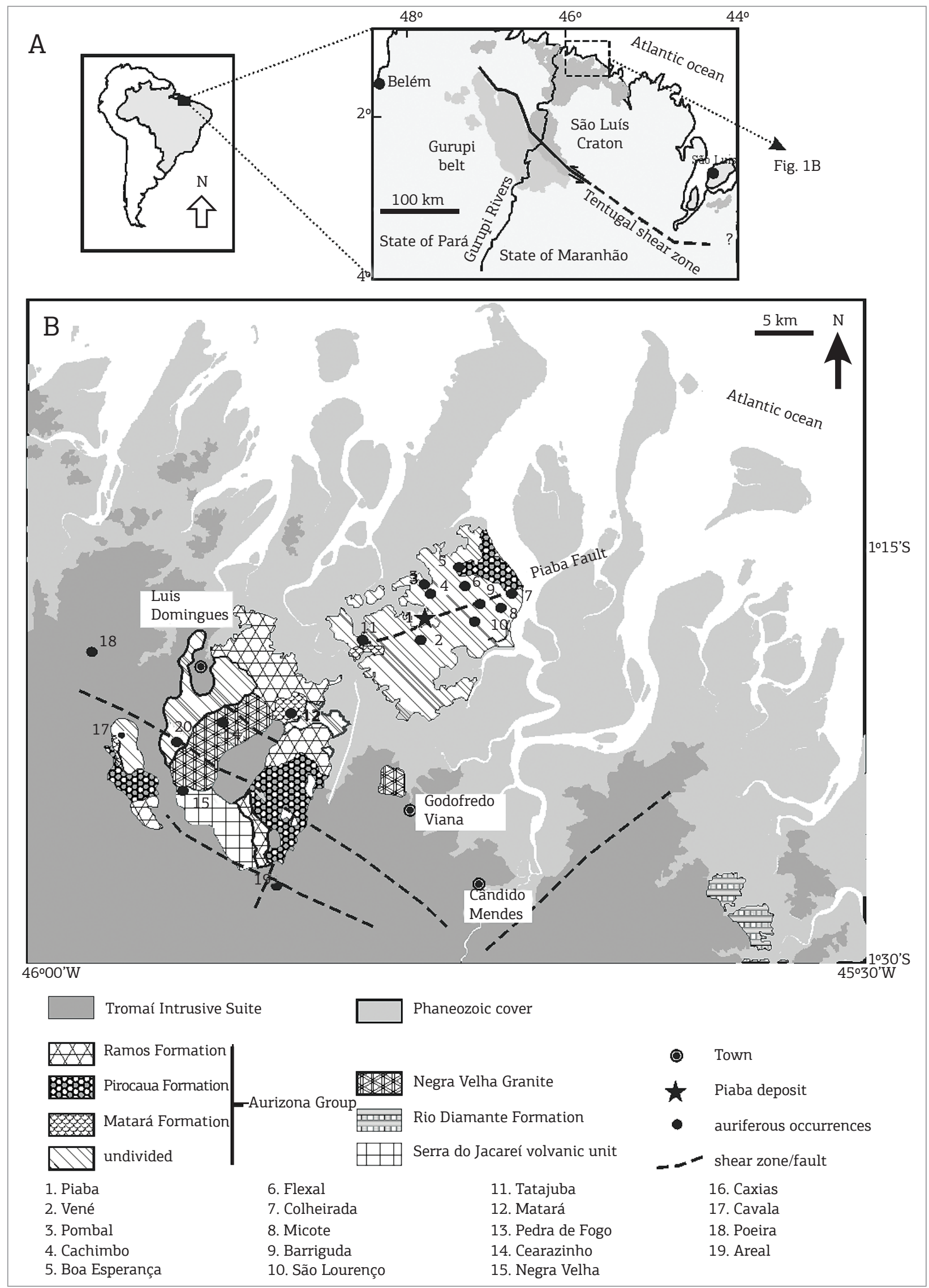

Figure 1. (A) Location map and (B) simplified geological map of the northern sector of the São Luís cratonic fragment with location of the main gold occurrences and of the Piaba deposit (adapted from Klein et al. 2008a). 
The main mineralization style is the stockwork geometry defined by gold-bearing quartz veins and veinlets that occupy the most fractured portions of the host rocks. Minor disseminations are also observed and are associated with sulfide concentrations in hydrothermally-altered host rocks. The ore bodies are located in a $300 \mathrm{~m}$-wide zone associated with the $\mathrm{N} 70^{\circ} \mathrm{E}$-trending, sub-vertical Piaba fault (Fig. 2A), which imparted intensive brittle deformation in the rocks. In depth, the ore bodies extend to at least $200 \mathrm{~m}$ and become narrower and coincident with the lower limit of the fractured zone (Fig. 2B). In this zone, host rocks are characterized by $\mathrm{mm}$ - to $\mathrm{cm}$-long small fractures, most of them filled with sericite, quart and Au. They mutually crosscut sub-horizontal and sub-vertical groups of fractures predominate.

The rocks in the Piaba deposit region have strongly been affected by lateritic weathering. As such, outcrops are rare and the geological information is better obtained through the investigation of drill cores. In this work, we have examined representative drill cores from a mineralized zone (drill 204, Fig. 2A) in an attempt to get a better definition of the host rock types. However, most of the investigated samples show strong effects of hydrothermal alteration, which hinders the characterization of the protoliths (Fig. 3A). Nevertheless, despite the strong alteration, two rock types have been observed in the studied section.

The first rock type is a little fractured, fine- to medium-grained with light grey to greenish colors, having local dissemination of pyrite (Fig. 3B). Under the microscope, the less altered portions of the rock show quartz $(25-35 \%)$, alkali feldspar $(-25 \%)$ and plagioclase $(-40 \%)$ in granular texture (Figs. 3C and D). Micrographic overgrowth is a common feature and is probably the cause of granophyre designation. Ilmenite is a common phase, whereas apatite and zircon are accessory phases. Quartz grains are anedric, little deformed, but in places they show undulose extinction and form subgrains. The contact with other phases is curved. The feldspars are subedric and display sharp contacts. Even the most preserved crystals show small laths of sericite. In most cases, the distinction of the type of feldspar is hindered by the alteration (Figs. 3B to D). However, assuming that the less altered portions are representative of the protoliths, these may be characterized as fine-grained granodiorites.

In the lower portion of the studied cross section, below depths of $161.2 \mathrm{~m}$ there is a finely laminated, lightgrey rock, which is only weakly altered. Locally, however, the lamination is disturbed by small fractures filled by quartz or quartz-carbonate-tourmaline-sulfide veinlets (Fig. 4). This rock is composed of an alternation of very thin $(<1 \mathrm{~mm})$ layers of microcrystalline quartz and even thinner layers of plagioclase, chlorite, sericite, carbon matter and rare quartz. This rock is interpreted as tuffaceous, in which the quartz layers may represent chert. Alternatively, it may be a tuffite that was deposited in subaqueous setting and mixed with materials derived from the reworking of recently-deposited volcanic products.

\section{Hydrothermal alteration}

Silicification is, volumetrically, the most important alteration type. It is represented by veins and $\mathrm{mm}$ - to $\mathrm{cm}$ wide veinlets of quartz that host a large portion of gold ore in the deposit (Figs. 5A and B). The quartz veins have multiple directions. Under the microscope, the quartz grains are anhedral to subhedral, little to moderately fractured, with local undulose extinction, and may occur in association with sulfide minerals. Apparently, there are two generations of quartz that differ basically according to grain morphology and thickness of the veins: anhedral grains filling mm-wide open fractures, and subhedral in thicker veins.

Sericitization and chloritization occur in spatial association. White mica (sericite) is the predominant phase of grey-colored rocks, whereas chlorite has higher contents in the shallower portions of the deposit, being associated with more fractured sectors and with higher contents of pyrite. The higher chlorite contents impart greenish colors to the rocks. Under the microscope, chlorite grains are mainly disseminated or forming oriented flakes in the pyrite margins (Fig. 5E) and ilmenite crystals, and also in the margins of quartz veins, and filling fractures and inter-granular contacts in the host rocks. The white mica is mostly observed as an alteration phase over the feldspars and, subordinately, forming micro shear-bands or filling fractures in association with quartz, chlorite and pyrite (Fig. 5F).

Sulfidation forms, in general, aggregates of sulfide minerals in small quartz veinlets, and also occur as dissemination. Pyrite is the predominant sulfide mineral and chalcopyrite is a subordinate phase. The pyrite grains are subhedral to euhedral. In addition, recrystallization and substitution of the ilmenite by the pyrite is also observed (Fig. 4). In shallower portions of the deposit, chalcopyrite occurs mostly as tiny inclusions in pyrite and ilmenite crystals. In depth, there is an increase in the chalcopyrite contents and the mineral occurs as dissemination.

Carbonatization occurs in spatial association with sulfidation. Locally, the contemporaneous precipitation of calcite and gold and the accompanying substitution of pyrite by calcite are observed (Figs. 5C and D). Carbonatization is a process that is also evident in the wall-rock (tuffite), where carbonate minerals fill inter-granular spaces and form microveinlets in association with quartz and sulfides (Figs. 4B and D). 


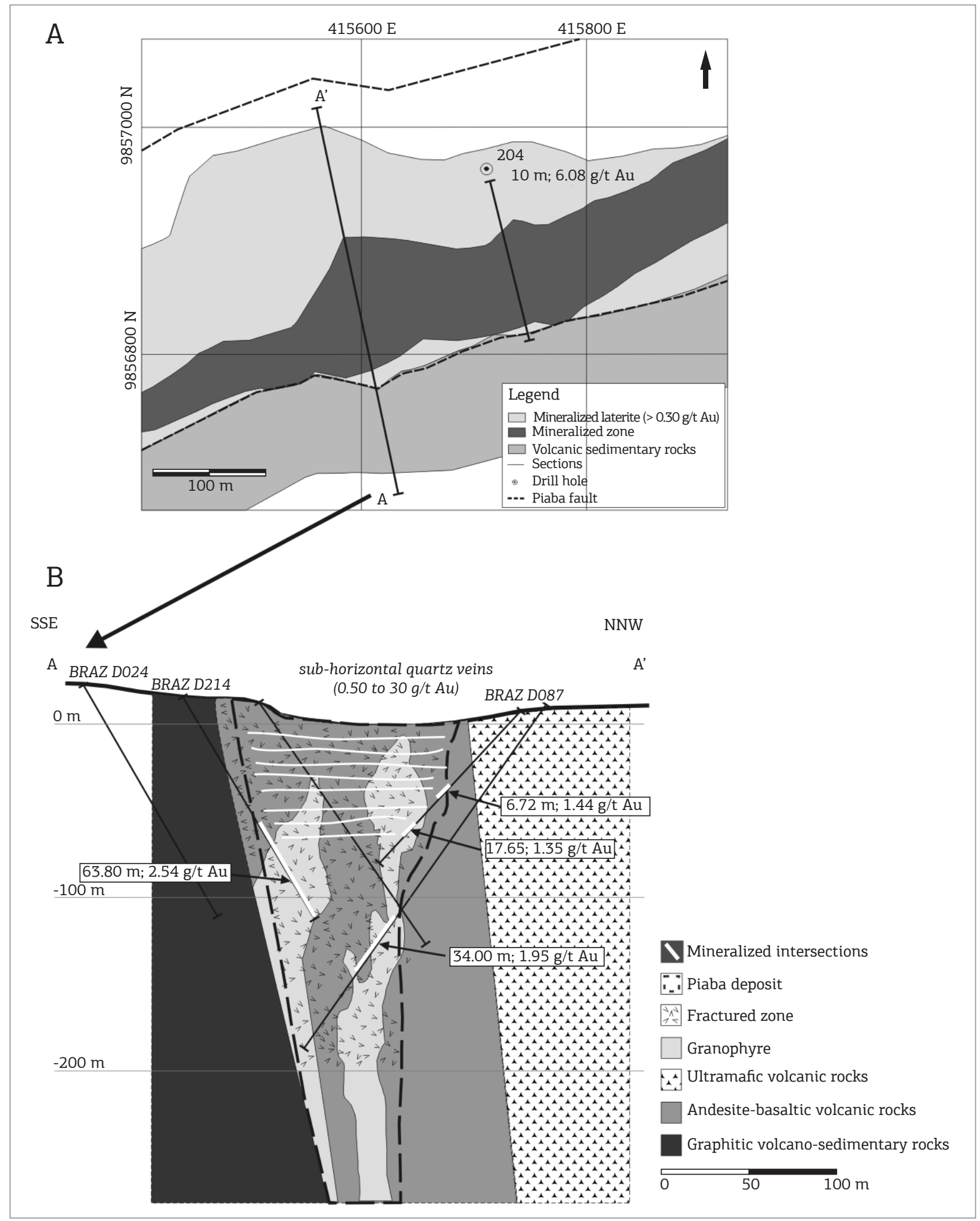

Figure 2. (A) Simplified geological map of the Piaba deposit showing the location of the drill 204, which is addressed in this study. (B) Cross section of the Piaba deposit (location in A) showing mineralized intersections with respective gold grades (modified from Lunagold 2011).

In the tuffite, the hydrothermal effects are from incipient to moderate, being represented by the presence of calcite occurring as dissemination in thin layers that are parallel to the lamination, and in discordant veinlets. These carbonate veinlets contain quartz, chlorite, brown tourmaline, ilmenite, pyrite and chalcopyrite (Figs. 4C and D). 


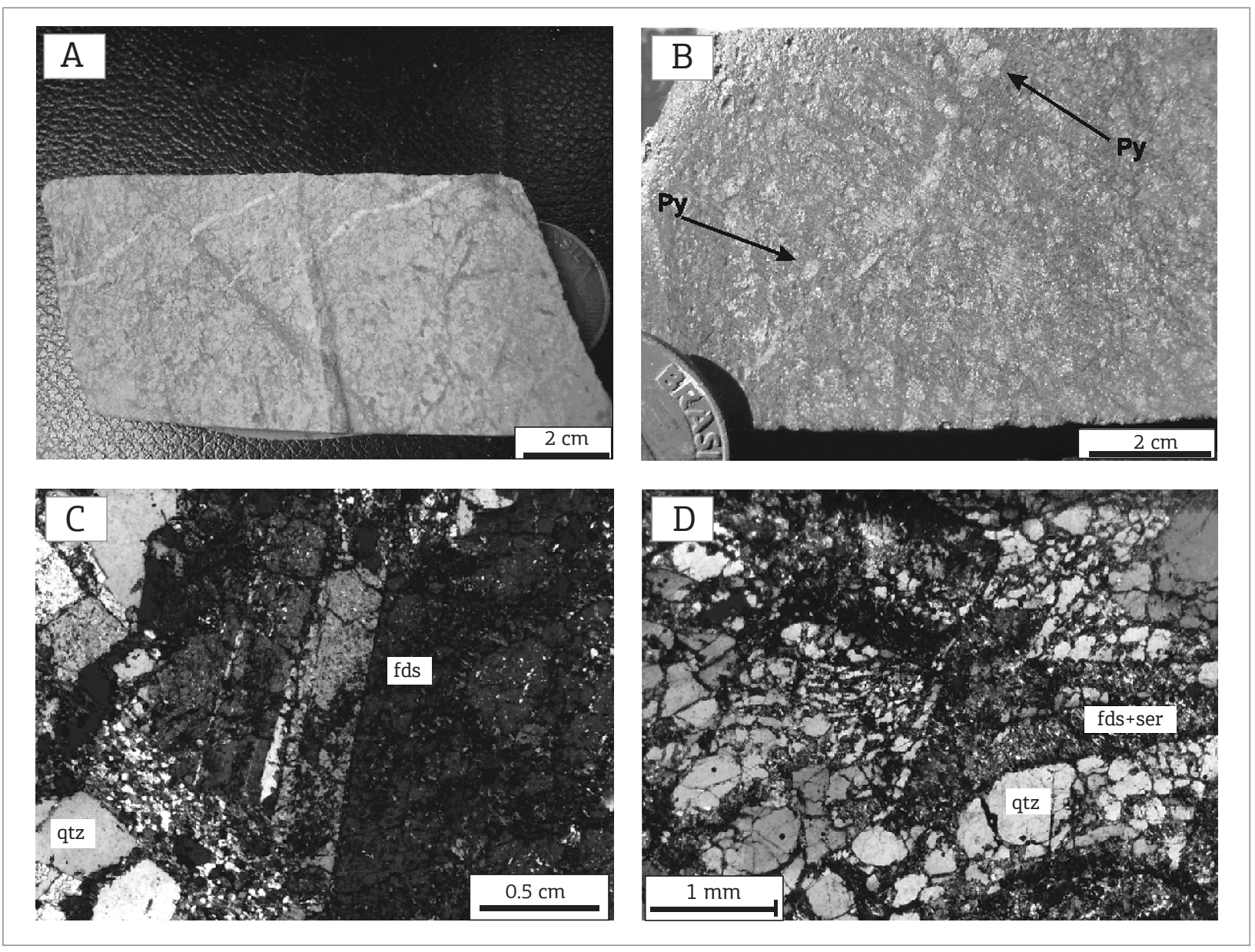

Figure 3. Drill core photographs (A-B) and photomicrographs of the host rocks at Piaba (C-D). Chloritized volcanic rock $(\mathrm{A})$ and fine-grained granophyric granodiorite $(\mathrm{B})$ in the less altered portions of the host rocks, where the feldspar twinnings are still preserved (C), while granophyric texture occurs in portions of brecciated samples (D). Mineral abbreviations: qtz: quartz; fds: feldspar; ser: sericite.

\section{Fluid inclusion studies}

\section{Analytical procedures}

The fluid inclusion studies were performed in quartz crystals from ore-related veinlets. Sample preparation and microthermometric analyses followed recommendations of Roedder (1984) and Shepherd et al. (1985). Petrographic and microthermometric studies were undertaken in laboratories of Instituto de Geociências at the Federal University of Pará, in Belém, Brazil, using a Linkham THMSG 600 at heating-freezing stage. Calibration was done with pure $\mathrm{CO}_{2}$ $\left(-56.6^{\circ} \mathrm{C}\right)$ and water $\left(0^{\circ} \mathrm{C}\right)$ synthetic standards. Precision is estimated in $\pm 0.3^{\circ} \mathrm{C}$ for temperature measurements below $30^{\circ} \mathrm{C}$ and $\pm 5^{\circ} \mathrm{C}$ for temperatures above $100^{\circ} \mathrm{C}$.

The microRaman studies were performed on a XY Dilor spectrometer equipped with multichannels in the Federal University of Minas Gerais, in Belo Horizonte, Brazil. The exiting source was an Argon laser with wavelength of $514.53 \mathrm{~nm}$ and power of $700 \mathrm{~mW}$. Molar proportions were determined using Plackzek's equation (Eq. 1) and the quantification factors related to the Raman effect were 1.21 for $\mathrm{CO}_{2}, 8.7$ for $\mathrm{CH}_{4}$ and 1 for $\mathrm{N}_{2}$ (Burke 2001). The quantification consists in comparing the peak areas (integrated intensities) through the (modified) equation:

$\mathrm{X}_{\mathrm{a}}=\left(\mathrm{A}_{\mathrm{a}} / \mathrm{F}_{\mathrm{a}}\right) / \Sigma\left(\mathrm{A}_{\mathrm{i}} / \mathrm{F}_{\mathrm{i}}\right)$

in which $\mathrm{X}_{2}, \mathrm{~A}_{2}$ and $\mathrm{F}_{2}$ are respectively molar fraction, peak area, and quantification factor of the component a; $\mathrm{A}_{\mathrm{i}}$ e $\mathrm{F}_{\mathrm{i}}$ are respectively the peak area and quantification factor for all the present components; $\Sigma$ is the total.

Eight double-polished thick sections, out of sixteen that were previously evaluated, were used in the studies. These cover about $68 \mathrm{~m}$, in depth, of the mineralized zone. About 380 fluid inclusions were analyzed. Data reduction and composition, density and isochore calculations were done with the Flincor software (Brown 1989). The following abbreviations 

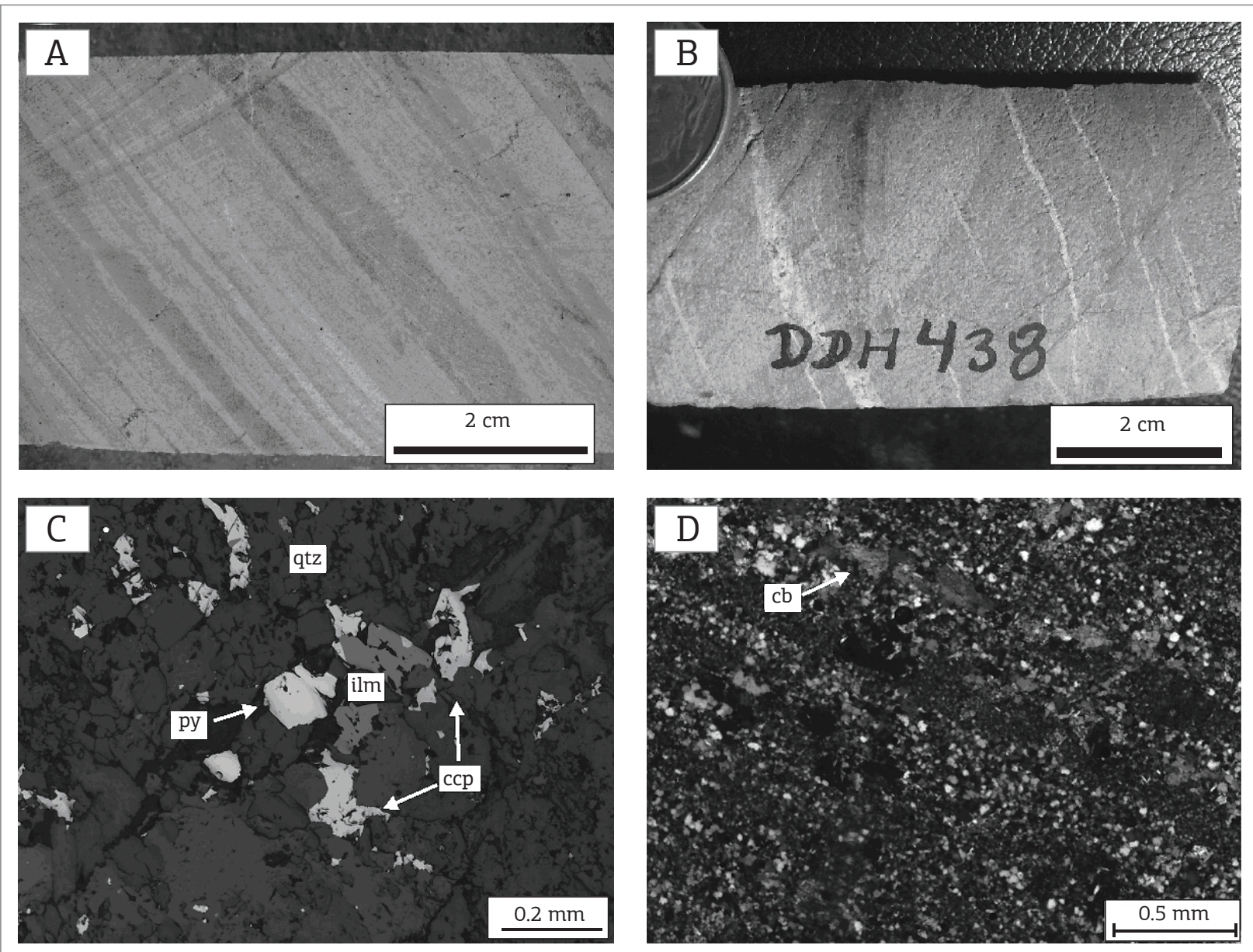

Figure 4. Mesoscopic aspect of the tuffite (A) without hydrothermal alteration and (B) crosscut by carbonate veinlets. At $(C)$ and (D) microscopic detail of sulfide and carbonates, respectively, deposited in fractures between the layers. Mineral abbreviations: ccp: chalcopyrite; ilm: ilmenite; cb: carbonate; qtz: quartz; py: pyrite.

are used in text, tables and figures: $\mathrm{T}_{\mathrm{MCO}_{2}}: \mathrm{CO}_{2}$ melting temperature; $\mathrm{T}_{\mathrm{MCLAT}}$ : clathrate melting temperature; $\mathrm{T}_{\mathrm{HCO}_{2}}: \mathrm{CO}_{2}$ (partial) homogenization temperature; $\mathrm{T}_{\mathrm{H}}$ : final homogenization temperature; $\mathrm{T}_{\mathrm{MICE}}$ : ice melting temperature; $\mathrm{T}_{\mathrm{EU}}$ : eutectic temperature. One phase, biphasic (two phases) and threephasic (three phases) refer to the number of fluid phases present at room temperature $\left(-22-24^{\circ} \mathrm{C}\right)$.

\section{Petrography, classification and distribution of fluid inclusions}

The gold-bearing quartz veins show weak signs of deformation, such as fractures (Fig. 6A), undulose extinction and subgrain formation. Knowing that such features might provoke post-trapping modifications, like partial leaking and necking down, the microthermometric analyses were concentrated in the less deformed and undeformed quartz crystals, in order to obtain information about the original ore-transporting fluid. At least four types of fluid inclusions have been described, in growing order of abundance:
Type I - Two phase inclusions are composed of a clear aqueous liquid phase and a grayish liquid carbonic phase (bubble). These inclusions occur as clusters or in isolation in the host crystals and, subordinately, in trails. They vary in size from 10 to $30 \mu \mathrm{m}$ and have ellipsoidal and mostly irregular morphology. The carbonic phase take up between 20 and $50 \%$ of the inclusion volume. When submitted to weak freezing $\left(\mathrm{T}-0^{\circ} \mathrm{C}\right)$, a third phase $\left(\mathrm{CO}_{2}\right.$ gas $)$ is nucleated. This type is classified as aqueous-carbonic (Figs. 6B, E and F).

Type II - Three phase inclusions that comprise a clear aqueous phase, a grayish liquid carbonic phase, and a darker gaseous carbonic bubble (Fig. 6D). These inclusions have morphologies, distribution form, and phase proportions similar to those of Type I. These inclusions are also classified as aqueous-carbonic and they coexist with Type I.

Type III - The grayish to dark one phase inclusions that occur in a small number with rectangular to polygonal morphologies. They occur in isolation in the central portions of the host crystals and in places at the margins 

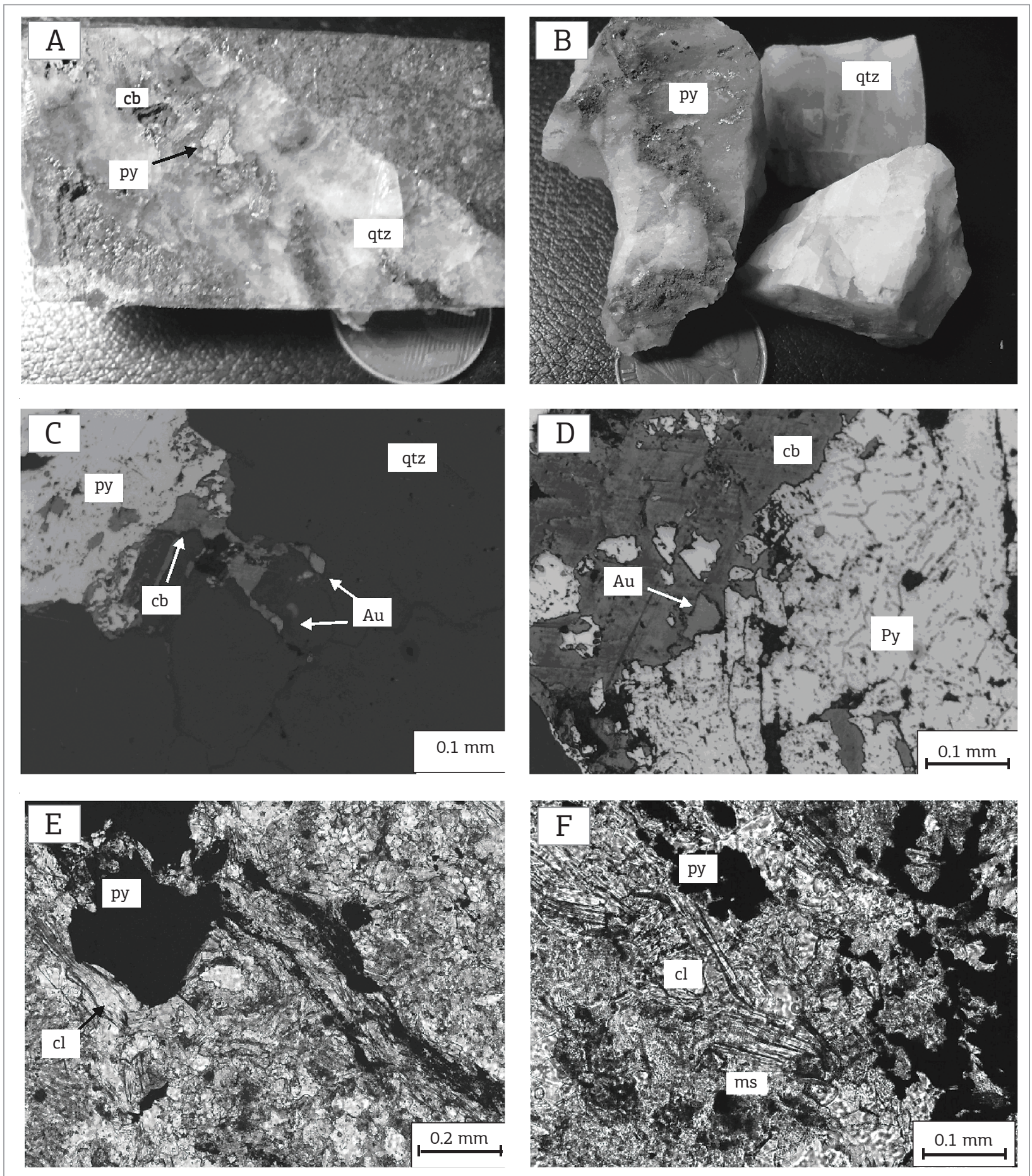

Figure 5. Mesoscopic (A - B) and microscopic (C - F) images showing the form of occurrence of the hydrothermal mineral assemblage at Piaba. Mineral abbreviations: Au: gold; qtz: quartz; py: pyrita; ms: muscovite; cl: chlorite; cb: carbonate.

of microfractutres. Under small temperature lowering, a second phase is nucleated. These are carbonic inclusions and they were not analyzed microthermometrically because they are small and show signs of leaking, especially near fractures.
Type IV - Two phase inclusions containing a very clear, limpid aqueous phase and a vapor bubble. These inclusions measure less than $10 \mu \mathrm{m}$ and occur in trails associated with microfracutres of the host quartz. They are interpreted as aqueous inclusions with degree of fill of $90-95 \%$. 


\section{Microthermometry and Raman microspectroscopy}

$\mathrm{CO}_{2}$ melting temperatures for types I and II were recorded between -56.6 e $-58.4^{\circ} \mathrm{C}$ (Fig. $8 \mathrm{~A}$ ). These values indicate that $\mathrm{CO}_{2}$ is the predominant volatile phase and that other phases are present only in subordinate amounts. This was confirmed by Raman microanalysis (Tab. 1 and Fig. 7) that revealed the presence of $\mathrm{CO}_{2}(100-97 \mathrm{~mol} \%), \mathrm{N}_{2}$ (up to $1 \mathrm{~mol} \%$ ) and $\mathrm{CH}_{4}$ (up to $1 \mathrm{~mol} \%$ ) as volatile phases.

In Type I inclusions, the $\mathrm{CO}_{2}$ (partial) homogenization temperatures range from 4 to $29^{\circ} \mathrm{C}$, with predominance of 6 to $10^{\circ} \mathrm{C}$. Type II also shows a wide range of values, from
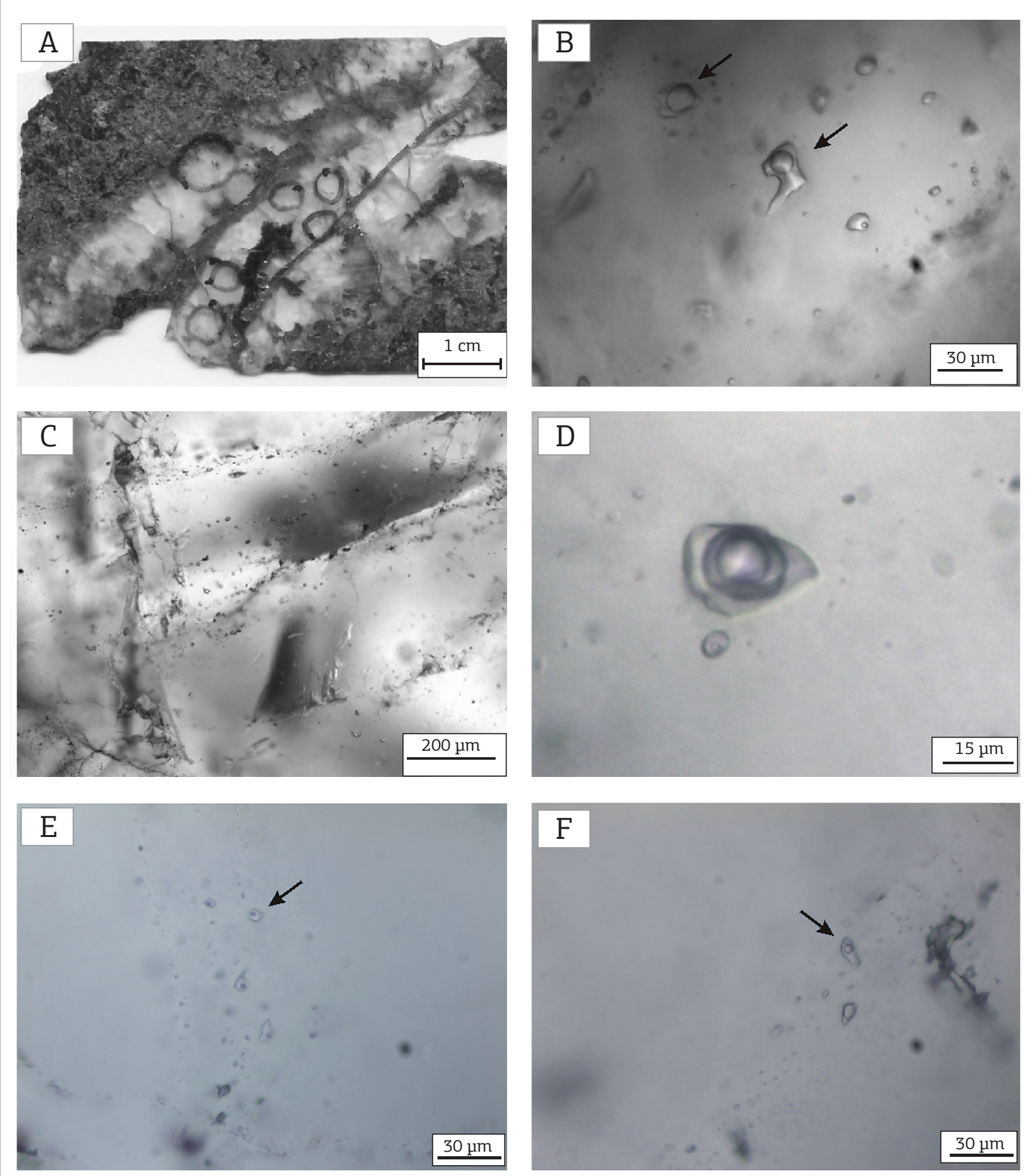

Figure 6. (A) Quartz veinlets with inclusion types (B - F) morphology, size and mode of distribution of the fluid inclusions. Type I (D), Type II (B, E, F) and Type III (C). 
7.4 to $28^{\circ} \mathrm{C}$ (Fig. $8 \mathrm{~B}$ ). It is worth noting that this variation occurs in a single microscopic domain of the host quartz. In both types, homogenization occurs to the liquid phase: $\mathrm{CO}_{2}(\mathrm{~L})+\mathrm{CO}_{2}(\mathrm{~V}) \rightarrow \mathrm{CO}_{2}(\mathrm{~L})$.

The clathrate melting, in types I and II, took place between 5.2 and $8.8^{\circ} \mathrm{C}$, mainly between 6 and $8^{\circ} \mathrm{C}$ (Fig. 9A). These values define salinities of 2.4 to 11.5 wt. $\% \mathrm{NaCl}$ equiv. (Collins 1979), with most values falling in the $5-7 \mathrm{wt} \%$ interval, and a mean value of 5.5 wt. $\% \mathrm{NaCl}$ equiv.

The final homogenization temperatures also show a wide range of values, from 183 to $377^{\circ} \mathrm{C}$ in the two-phase Type I inclusions, and from 220 to $340^{\circ} \mathrm{C}$ in the threephase Type II inclusions. In both types, the predominant interval of $\mathrm{T}_{\mathrm{H}}$ is $250-300^{\circ} \mathrm{C}$ (Fig. 9B), always to the liquid phase.

Limited microthermometric measurements performed in the aqueous inclusions show eutectic temperatures between -58 and $-31.1^{\circ} \mathrm{C}$. These values indicate the presence of other salt components in addition to $\mathrm{NaCl}$, which might be $\mathrm{CaCl}_{2}$ and $\mathrm{MgCl}_{2}$ (Shepherd et al. 1985). The TMICE values range from -28.3 to $-2^{\circ} \mathrm{C}$, and the final homogenization was recorded between 123 and $166^{\circ} \mathrm{C}$ (Fig. 10). The salinity for this aqueous type is 3.3 to > 23.1 wt. $\% \mathrm{NaCl}$ equiv.

\section{Interpretation of fluid inclusion data}

\section{Composition and density}

Composition, density and isochores were calculated from microthermometric and petrographic data using the Flincor software (Brown 1989). The calculations were done based on the equation of Bowers and Helgeson (1983) for the aqueous-carbonic fluids, which are the predominant type and that more probably acted in the ore transport and precipitation. The following compositional values were determined: $\mathrm{XCO}_{2}: 5-24 \mathrm{~mol} \%$ (predominantly $10-20 \mathrm{~mol} \%$ ); $X \mathrm{H}_{2} \mathrm{O}: 74-93 \mathrm{~mol} \%$ (predominantly $80-90 \mathrm{~mol} \%) ; X \mathrm{NaCl}: 0-1 \mathrm{~mol} \% ; X \mathrm{~N}_{2}$ : up to $1 \mathrm{~mol} \%$ and $\mathrm{XCH}_{4}$ : up to $1 \mathrm{~mol} \% . \mathrm{CO}_{2}$ densities vary from 0.63 to $0.88 \mathrm{~g} / \mathrm{cm}^{3}$, with predominance of values of $0.81-0.88 \mathrm{~g} / \mathrm{cm}^{3}$; global densities are in the interval $0.82-1.00 \mathrm{~g} / \mathrm{cm}^{3}$, predominantly $0.96-0.99 \mathrm{~g} / \mathrm{cm}^{3}$. The average salinity for the aqueous-carbonic types is $5.5 \mathrm{wt} . \% \mathrm{NaCl}$ equivalent.

\section{Origin of the fluid inclusions (phase separation)}

In order to provide a better definition for the origin of the fluid inclusions from Piaba, we paid attention to the effects of deformation shown by the presence of microfractures, undulose extinction and recovery features such as the development of subgrains into quartz, which could have imparted significant changes in the physicochemical characteristics of the original fluid inclusions. As a consequence, only fluid inclusions occurring in microscopic domains in which post-entrapment effects were minimal have been analyzed microthermometrically. In addition, data coming from fluid inclusion that showed or might have shown some kind of post-entrapment modification have been discarded. This is reinforced by the $T_{H}$ versus salinity plot (Fig. 11), which usually shows cases in which necking-down and leaking under heating have occurred (Shepherd et al. 1985).

Assuming that post-entrapment changes have not influenced the data presented here, the absence of correlation between $\mathrm{T}_{\mathrm{H}}$ and salinity (Fig. 11) leads to other original causes for the interpretation of the microthermometric dataset, such as phase separation (Ramboz et al. 1982) or the unmixing of an originally homogeneous fluid
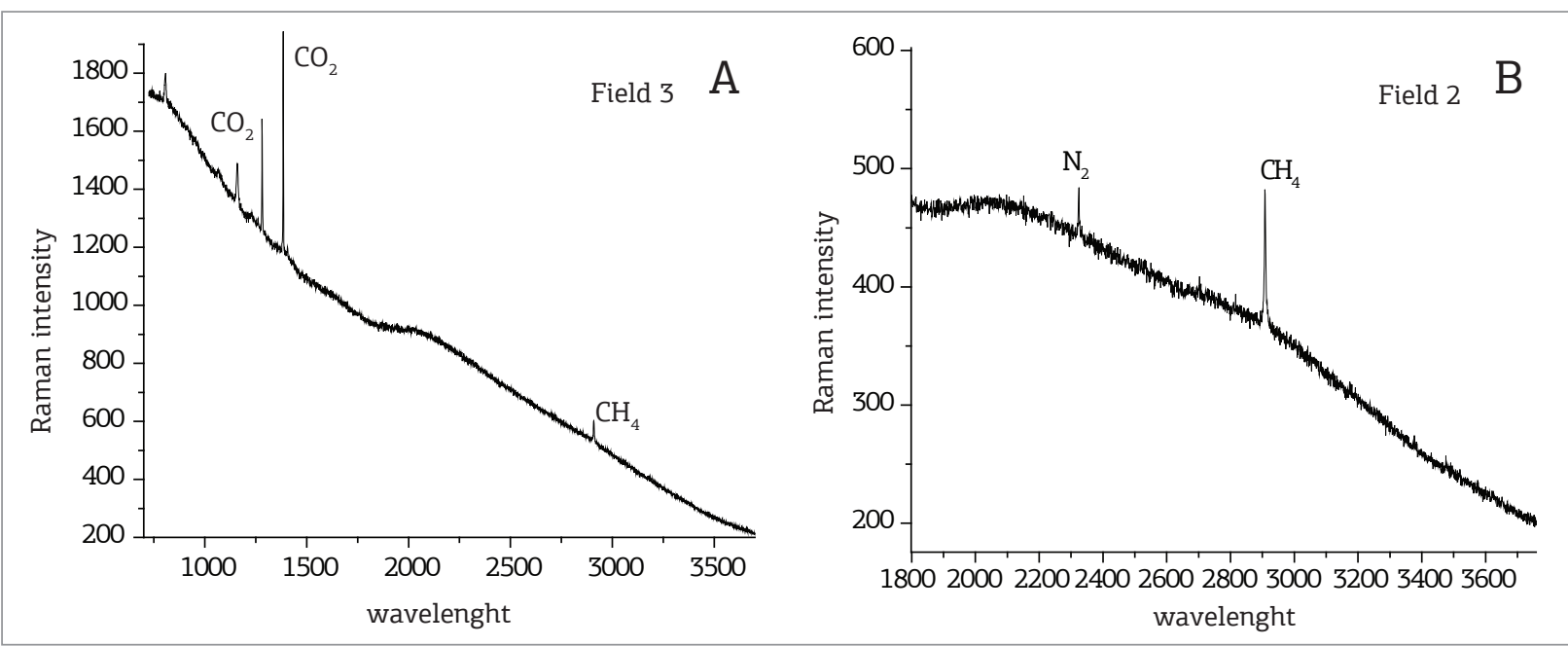

Figure 7. Raman spectra showing the presence of $\mathrm{CH}_{4}$ and $\mathrm{N}_{2}$ in fluid inclusions from Piaba. 


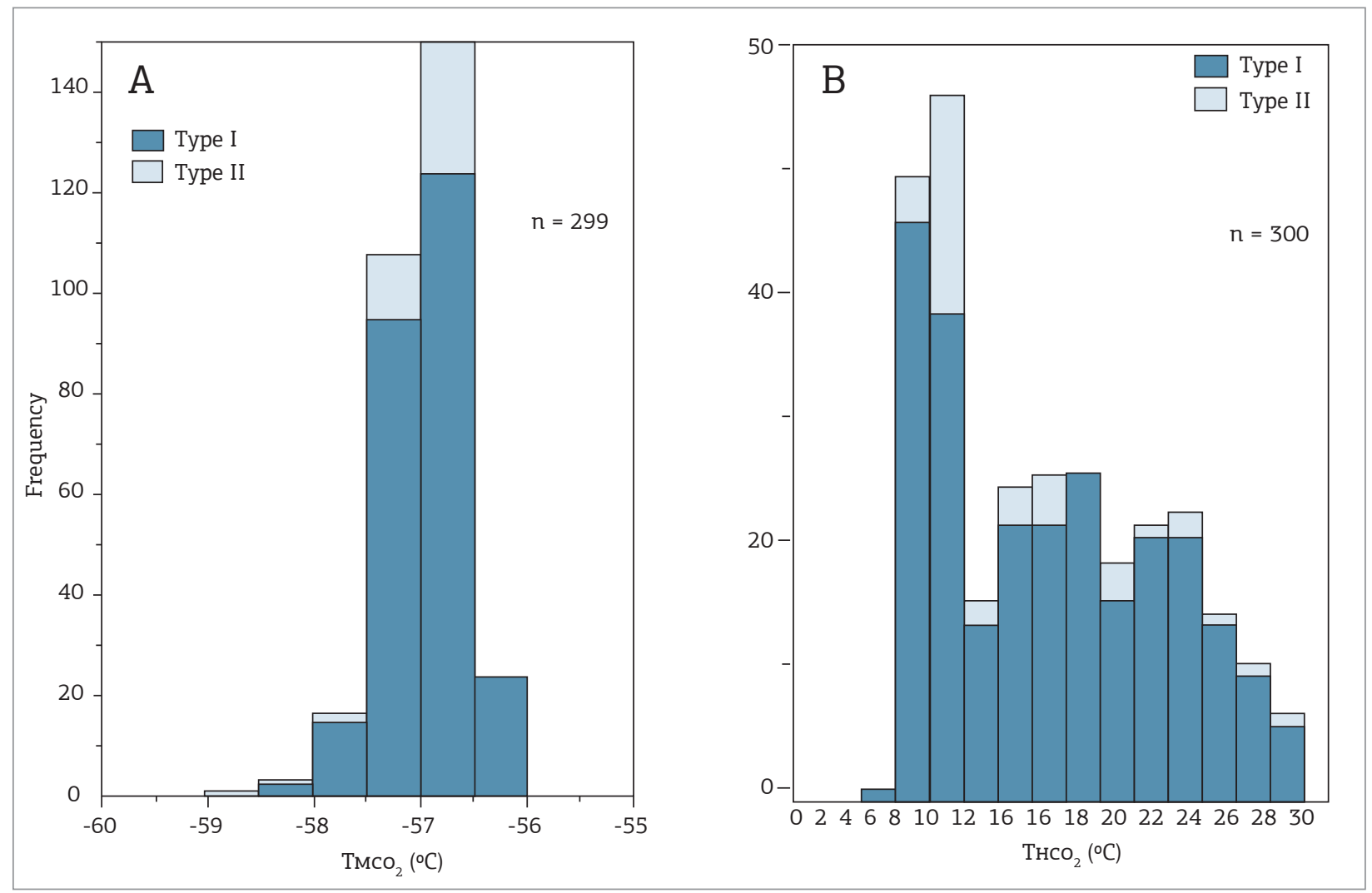

Figure 8. Frequency histograms for (A) $\mathrm{T}_{\mathrm{MCO}_{2}}-\mathrm{CO}_{2}$ melting temperature and (B) $\mathrm{T}_{\mathrm{HCO}_{2}}-\mathrm{CO}_{2}$ homogenization temperature in aqueous-carbonic fluid inclusions.
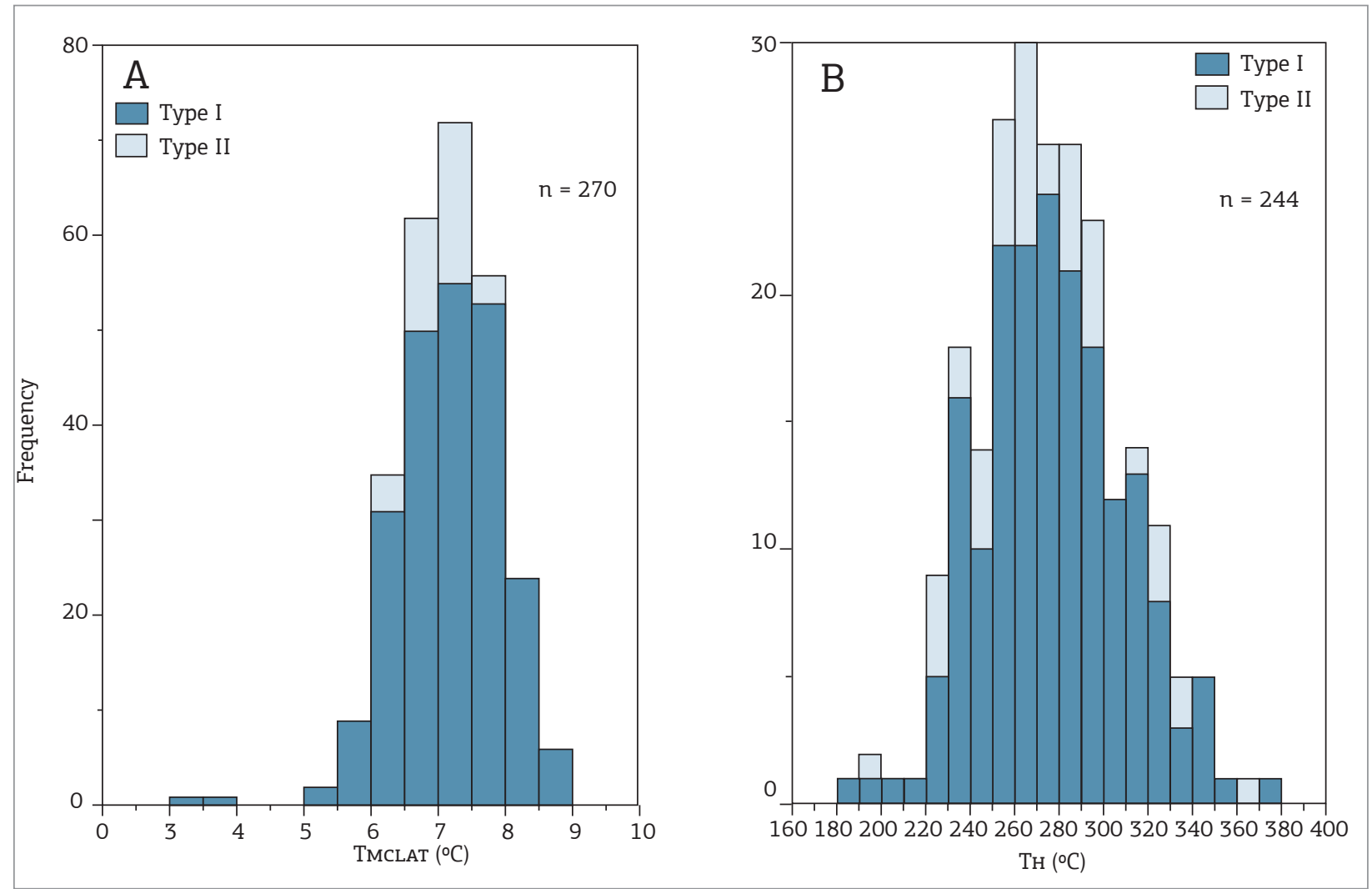

Figure 9. Frequency histograms for (A) TMCLAT - clathrate melting temperature and (B) TH - final homogenization for types I and II aqueous-carbonic fluid inclusions. 


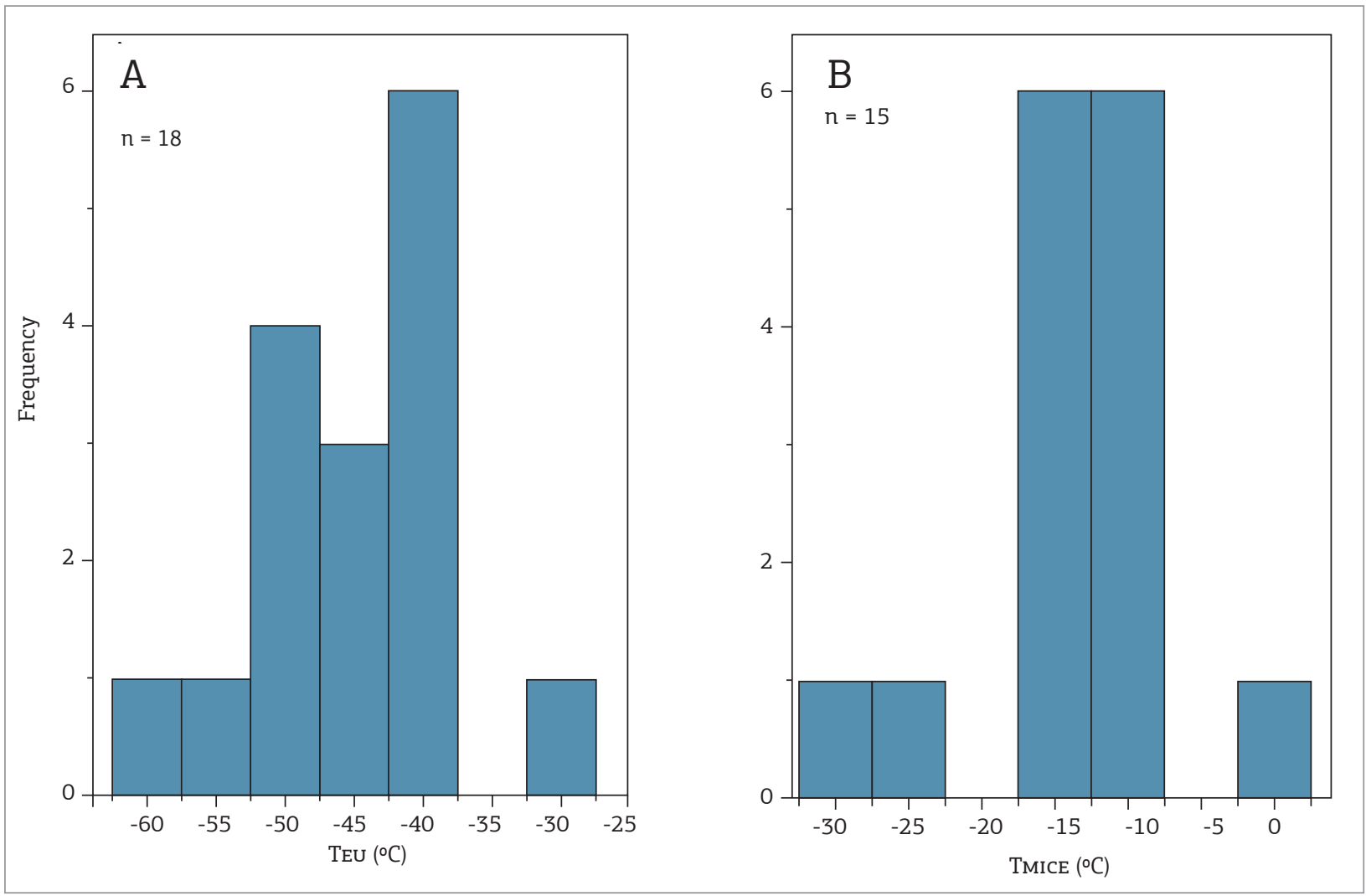

Figure 10. Frequency histograms for the aqueous fluid inclusions. (A) Eutectic melting temperature - TEU; (B) ice melting temperature - TMICE.

(according to Anderson et al. 1992), which also means phase separation; partial mixing; or heterogeneous trapping of two distinct homogeneous fluids.

The petrographic and microthermometric data show that aqueous-carbonic inclusions of Piaba have characteristics that may be attributed to trapping conditions, in which two or more fluid phases are present, that is, heterogeneous trapping of a fluid that had their phases separated in the hydrothermal process (Ramboz et al. 1982). These characteristics include the coexistence of types I, II and III with variable $\mathrm{CO}_{2} / \mathrm{H}_{2} \mathrm{O}$ ratios, variations in density, final homogenization temperature (liquid + vapor à liquid, in most of the analyses), and global composition. These differences are observed in both microscopic domains of a single crystal and throughout the whole set of analyzed samples. The heterogeneous trapping may occur through temperature and pressure changes and fluid-rock interactions, which could have provoked the fluid phase separation at Piaba.

\section{Influence of $\mathrm{CH}_{4}$ and $\mathrm{N}_{2}$}

Volatile compounds such as $\mathrm{CH}_{4}$ and $\mathrm{N}_{2}$ that are present in aqueous-carbonic fluid inclusions may affect the microthermometric results of these inclusions, producing overestimated salinity values, for instance (Seitz \& Pasteris

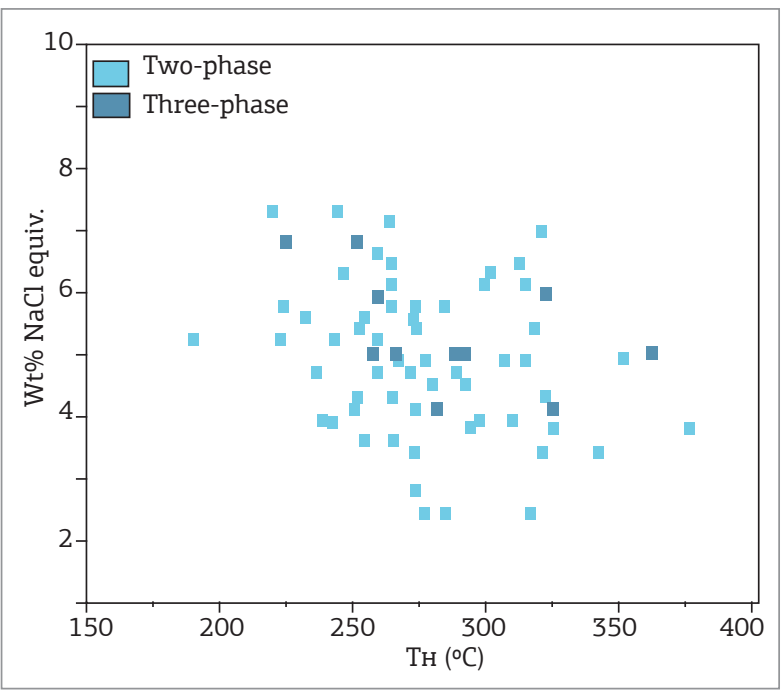

Figure 11. Final homogenization temperature versus salinity plot for the biphasic and threephasic aqueouscarbonic fluid inclusions (types I and II, respectively) of Piaba. Note the absence of covariation between the properties in the two types.

1990). However, it is also known that in low molar concentrations, as observed in Piaba, these modifications are insignificant and do not affect the original microthermometric results. 
In Piaba, only small differences in salinity and density of $\mathrm{CH}_{4}$ and $\mathrm{N}_{2}$ - bearing inclusions (Fig. 7) were observed, when compared with those of $\mathrm{CO}_{2}$ - only fluid inclusions. The $\mathrm{CH}_{4}$ and $\mathrm{N}_{2}$ content of the inclusions show inverse covariation with the $\mathrm{CO}_{2}$ melting temperature, but this is random in the analyzed samples. On the other hand, $\mathrm{CO}_{2}$ homogenization temperatures have not shown any evident relationship with the presence of $\mathrm{CH}_{4}$ and $\mathrm{N}_{2}$.

As possible sources for the presence of $\mathrm{CH}_{4}$ and $\mathrm{N}_{2}$ in the aqueous-carbonic fluids there are the carbonaceous host rocks of the Aurizona Group, described for the Piaba deposit. This fact has already been described for other gold deposits hosted in shear zones (e.g., Shepherd et al. 1991, Klein et al. 2006).

P-T- $f \mathrm{O}_{2}$ In the absence of external geothermometers, and assuming phase separation, as suggested by the microthermometric data, the temperature, pressure and crustal depth in which Piaba has been formed have been determined according to Hagemann \& Brown (1996). As such, isochores have been calculated for the whole interval of homogenization temperatures of the aqueous-carbonic fluid inclusions $\left(267-302^{\circ} \mathrm{C}\right)$ and for the variation limits of $\mathrm{CO}_{2}$ densities. In the P-T plot, calculated isochores intercept the solvus of the $\mathrm{CO}_{2}-\mathrm{H}_{2} \mathrm{O}-\mathrm{NaCl}$ system and define pressures between 1.25 and 2.08 kbars (Fig. 12). These values indicate hypozonal to mesozonal depths of 4 to $7 \mathrm{~km}$, which is consistent with the brittle-ductile deformation regime that was observed in the petrographic study, and is also consistent with the local geology.

Oxygen fugacity has been calculated for the whole $\mathrm{XCO}_{2}$ interval and for the T-P conditions determined above, using the equations and equilibrium constants of Ohmoto and Kerrick (1977) and the fugacity coefficients of Ryzhenko and Volkov (1971). Accordingly, values of $f \mathrm{O}_{2}$ ranging from -31.3 and -34.3 have been calculated (Fig. 13). These values are placed between the pyrite-magnetite/pyrrhotite and hematite/magnetite buffers, above the $\mathrm{CO}_{2}-\mathrm{CH}_{4}$ buffer and below the $\mathrm{SO}_{2}-\mathrm{H}_{2} \mathrm{~S}$ buffer. These values characterize a relatively reduced ore fluid (Ohmmoto and Goldhaber 1997) for the Piaba deposit.

\section{Discussion and conclusion}

The host rocks and the veins and veinlets of Piaba revealed important information about ore paragenesis and physicochemical characteristics of the fluids that transported and precipitated the gold ore. The petrographic study suggests that host rocks underwent intense hydrothermal

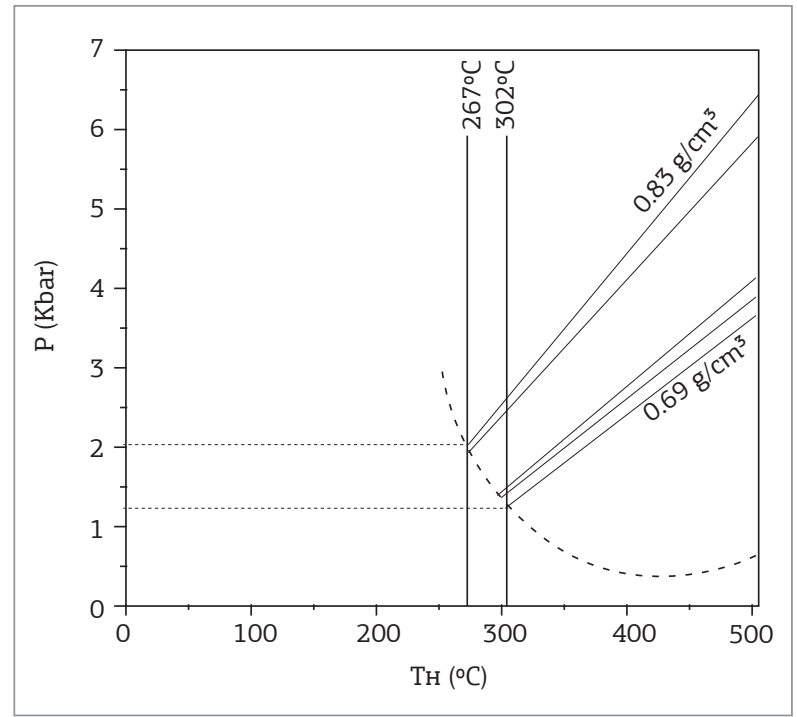

Figure 12. Diagram showing the estimated P-T conditions for the gold mineralization in Piaba. The dashed line represents the solvus for the $\mathrm{CO}_{2}-\mathrm{H}_{2} \mathrm{O}-\mathrm{NaCl}$ system $\left(10 \mathrm{~mol} \% \mathrm{CO}_{2}\right.$ and $6 \% \mathrm{NaCl}$ ) as determined by Bowers and Helgeson (1983).

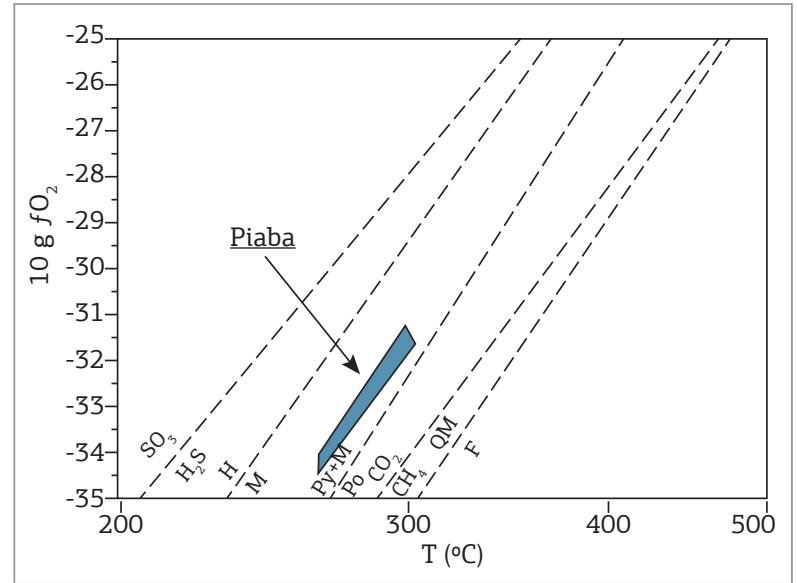

Figure 13. Diagram T- $f \mathrm{O}_{2}$ showing the redox conditions estimated for gold mineralization at Piaba. References for the solid and liquid buffers in (Ohmoto and Goldhaber 1997). Mineral abbreviations: Py: pyrite; Po: pyrrhotite; H: hematite; M: magnetite.

Table 1. Composition of the volatile phases in aqueous-carbonic fluid inclusions of the Piaba gold deposit, based on microthermometric and Raman spectroscopic data

\begin{tabular}{l|c|c|c|c|c|c|c|c|c}
\hline Sample & Type & $\mathbf{V C O}_{2}(\%)$ & $\mathrm{T}_{\mathrm{MCO2}}\left({ }^{\circ} \mathrm{C}\right)$ & $\begin{array}{c}\mathrm{T}_{\mathrm{HCO}} \\
\left({ }^{\circ} \mathrm{C}\right)^{2}\end{array}$ & $\begin{array}{c}\mathrm{T}_{\mathrm{MCLAT}} \\
\left({ }^{\circ} \mathrm{C}\right)\end{array}$ & $\mathrm{T}_{\mathrm{H}}\left({ }^{\circ} \mathrm{C}\right)$ & $\mathbf{C O}_{2} \%$ & $\mathbf{C H}_{4}(\%)$ & $\mathbf{N}_{2}(\%)$ \\
\hline 1022 B - 1 & $\mathrm{I}$ & 30 & -57.5 & 8.5 & 7.0 & 274 & 99 & $\leq 1$ & - \\
\hline 1022 B - 2 & $\mathrm{I}$ & 30 & -57.5 & 16.8 & 8.2 & 291 & 98 & $\leq 1$ & 0 \\
\hline 1022 B - 3 & $\mathrm{I}$ & 25 & -57.4 & 22.1 & 8.1 & 285 & 97 & $\leq 1$ & $\leq 1$ \\
\hline
\end{tabular}


alteration caused by the mineralizing fluid that formed sericite, chlorite, carbonate, sulfide minerals (pyrite, chalcopyrite) and gold.

The fluid inclusion study showed that most of the inclusions are aqueous-carbonic and primary in nature, and that these inclusions are the most important ones regarding the processes that formed the Piaba deposit. Petrographic observations and microthermometric and Raman analyses, combined with the ore mineral paragenesis, indicate that the ore-transporting fluid is composed of: $X \mathrm{CO}_{2}: 10-20 \mathrm{~mol} \%$; $X \mathrm{H}_{2} \mathrm{O}: 80-90 \mathrm{~mol} \% ; X \mathrm{NaCl}$ : $0-1 \mathrm{~mol} \%$ and $X \mathrm{~N}_{2}$ and $X \mathrm{CH}_{4}$ : up to $1 \mathrm{~mol} \%$ each. Some variations observed in the partial $\left(\mathrm{T}_{\mathrm{HCO}_{2}}\right)$ and final $\left(\mathrm{T}_{\mathrm{H}}\right)$ homogenization temperatures of the fluid inclusions may be explained as a result of heterogeneous trapping during phase separation of two immiscible fluids, since post-entrapment changes have not been significant in this deposit.

Based on the fluid inclusion trapping conditions, the gold ore was precipitated between 267 and $302^{\circ} \mathrm{C}$, and 1.25 to 2.08 kbars. These conditions are consistent with the formation of the deposit under brittle-ductile regime, in mesozonal to epizonal depths.

Taking into account the $T, P, V, X, f \mathrm{O}_{2}$ conditions operating during ore precipitation, and the presence of pyrite as the main sulfide mineral in the alteration assemblage, it is likely that $\mathrm{H}_{2} \mathrm{~S}$ was present in the fluid and that gold was transported as a bisulfide complex, such as $\mathrm{Au}(\mathrm{HS})_{2}$ - or $\mathrm{HAu}(\mathrm{HS})_{2}^{0}$ (Benning and Seward 1996). The destabilization of the transporting complex might have occurred as a consequence of phase separation and/or the reaction of the fluid with carbon-bearing host rocks, which might have developed the necessary conditions for the sulfidation of the host rocks and fluid reduction.

Geological characteristics such as host rocks and alteration mineralogy, as well as the fluid characteristics observed in the Piaba deposit, are quite similar to those described by Klein et al. (2005b and references therein) for other gold occurrences in the same region (Tab. 2). Although isotopic data are not yet available to Piaba, the isotopic data for the Caxias prospect indicate a metamorphic nature for the mineralizing fluid (Klein et al. 2005b). These authors interpreted the geological and genetic characteristics of Caxias and the other occurrences as being compatible with those of the class of orogenic gold deposits (Groves et al. 1998), which is here assumed as being valid for Piaba.

\section{Acknowledgements}

This work was made possible by the access to drill cores of the Piaba deposit, which have been kindly provided by Dr. Titus Haggan (Luna Gold), and by the financial support provided by CNPq (Edital Universal, MCT/CNPq 14/2009, process 481.189/2009-2). Dr. Kazuo Fuzikawa (CDTN/CNEN) and Dr. Maria Sylvia Dantas (UFMG) are acknowledged for their support with the microRaman analyses. We also thank CNPq for the scholarship to SCFF and research Grant to ELK. The comments and suggestions of Dr. Luiz José Homem D’el-Rey Silva greatly improved the original manuscript.

Table 2. Mineralogical characteristics and physicochemical parameters for Piaba and other gold deposits of the São Luís cratonic fragment (Klein et al. 2005b)

\begin{tabular}{l|c|c|c|c|c}
\hline Deposit & \multicolumn{1}{|c|}{ Mineral assemblage } & Fluid composition & $\mathbf{P}$ (Kbar) & $\log \mathbf{f O}_{2}$ & $\mathbf{T}\left({ }^{\circ} \mathbf{C}\right)$ \\
\hline Piaba & $\mathrm{Qtz}+\mathrm{Cb}+\mathrm{Cl}+\mathrm{Ser}+\mathrm{Py}+\mathrm{Ccp}+\mathrm{Au}$ & $\mathrm{CO}_{2}+\mathrm{H}_{2} \mathrm{O}+\mathrm{N}_{2}+\mathrm{CH}_{4}$ & $1.25-2.08$ & -31.3 to -34.3 & $267-302$ \\
\hline Areal $^{*}$ & $\mathrm{Qtz}+\mathrm{Cb}+\mathrm{Cl}+\mathrm{Ser}+\mathrm{Sph}+\mathrm{Ep}+\mathrm{Py}+\mathrm{Au}$ & $\mathrm{CO}_{2}+\mathrm{H}_{2} \mathrm{O}+\mathrm{N}_{2}$ & $1.6-3.7$ & -29.8 to -34.2 & $262-307$ \\
\hline Caxias* $^{*}$ & $\mathrm{Qtz}+\mathrm{Cb}+\mathrm{Cl}+\mathrm{Ser}+\mathrm{Sph}+\mathrm{Ep}+\mathrm{Py}+\mathrm{Au}$ & $\mathrm{CO}_{2}+\mathrm{H}_{2} \mathrm{O}+\mathrm{N}_{2}+\mathrm{CH}_{4}$ & $2.4-4.6$ & -29.8 to -34.2 & $262-307$ \\
\hline Pedra de Fogo* & $\mathrm{Qtz}+\mathrm{Cl}+\mathrm{Ser}+\mathrm{Py}+\mathrm{As}+\mathrm{Au}$ & $\mathrm{CO}_{2}+\mathrm{H}_{2} \mathrm{O}+\mathrm{N}_{2}+\mathrm{CH}_{4}$ & 2 & n.d & $330-400$ \\
\hline
\end{tabular}

n.d: not determined. Mineral abbreviations: Cb: carbonate; $\mathrm{Cl}$ : chlorite; Ser: sericite; Ep: epidote; Sph: sphalerite, Py: pyrite; Ccp: chalcopyrite

\section{REFERENCES}

Anderson M.R., Rankin A.H., Spiro B. 1992. Fluid mixing in the generation of mesothermal gold mineralization in the Transvaal sequence, Transvaal, South Africa. European Journal of Mineralogy, 4(5):933-948.

Benning L.G \& Seward T.M. 1996. Hydrosulphide complexing of Au (I) in hydrothermal solutions from 150 to $400^{\circ} \mathrm{C}$ and 500 to 1,500 bars. Geochimica et Cosmochimica Acta, 60(11):1849-1871.

Bowers T.S \& Helgeson H.C. 1983. Calculation of the thermodynamic and geochemical consequences of nonideal mixing in the system $\mathrm{H} 2 \mathrm{O}-\mathrm{CO} 2-\mathrm{NaCl}$ on phase relations in geological systems: equation of state for $\mathrm{H}_{2} \mathrm{O}-\mathrm{CO}_{2}-\mathrm{NaCl}$ fluids at high pressures and temperatures. Geochimica et Cosmochimica Acta, 47(7):1247-1275.

Brown P.E. 1989. Flincor: a microcomputer program for the reduction and investigation of fluid inclusion data. American Mineralogy, 74(11,12):1390-1393.

Burke E.A.J. 2001. Raman microspectrometry of fluid inclusions. Lithos, 55(1-4):139-158.

Collins P.L.F. 1979. Gas hydrates in $\mathrm{CO}_{2}$-bearing fluid inclusions and the use of freezing data for estimation of salinity. Economic Geology, 74(6):1435-1444. 
Costa J.L. 2000. Programa Levantamentos Geológicos Básicos do Brasil. Programa Grande Carajás. Castanhal. Folha SA. 23-V-C. Estado do Pará. Belém, CPRM.

Groves D.I., Goldfarb R.J., Gebre-Mariam M., Hagemann S.G., Robert F. 1998. Orogenic gold deposits: a proposed classification in the context of their crustal distribution and relationship to other gold deposit types. Ore Geology Reviews, 13(1-5):7-27.

Hagemann S.G \& Brown P.E. 1996. Geobarometry in Archean lodegold deposits. European Journal of Mineralogy, 8(5):937-960.

Klein E.L \& Moura C.A.V. 2001. Age constraints on granitoids and metavolcanic rocks of the São Luis Craton and Gurupi belt, northern Brazil: implications for lithostratigraphy and geological evolution. International Geology Review, 43(3):237-253.

Klein E.L., Moura C.A.V., Pinheiro B.L.S. 2005a. Paleoproterozóic crustal evolution of the São Luís Craton, Brazil: evidence from zircon geochronology and Sm-Nd isotopes. Gondwana Research, 8(2):177-186.

Klein E.L., Moura, C.A.V., Harris C., Giret A. 2005b. Reconnaissance Stable Isotope (C, O, H, S) Study of Paleoproterozoic Gold Deposits of the São Luis Craton and Country Rocks, Northern Brazil: Implications for Gold Metallogeny. International Geology Review, 47(11):1131-1143.

Klein E.L., Harris, C., Renac C., Giret A., Moura C.A.V., Fuzikawa K. 2006. Fluid inclusion and stable isotope (O, H, C, and S) constraints on the genesis of the Serrinha gold deposit, Gurupi Belt, northern Brazil. Miner Deposita, p. 160-178.

Klein E.L \& Moura C.A.V. 2008. São Luís Craton and Gurupi Belt (Brazil): possible links with the West African Craton and surrounding Pan-African belts. West Gondwana: Pre-Cenozoic Correlations Across the South Atlantic Region. In: Pankhurst, R.J., Trouw, R.A.J., Brito Neves, B.B., De Wit, M.J. (eds). Geological Society, London, Special Publications, 294, p. 137-151.

Klein E.L., Marinho P.A.C., Rosa-Costa L.T. Da, Larizzatti J.H., Faraco M.T.L. 2008a. Geologia e Recursos Minerais da Folha Cândido Mendes - SA.23V-D-II, Estado do Maranhão, Escala 1:100.000. Belém: CPRM, 150 p.

Klein E.L., Luzardo R., Moura C.A.V., Armstrong R.A. $2008 \mathrm{~b}$. Geochemistry and zircon geochronology of paleoproterozoic granitoids: Further evidence on the magmatic and crustal evolution of the São Luís cratonic fragment, Brazil. Precambrian Research, 165:221-242.

Klein E.L., Luzardo R., Moura C.A.V., Lobato D.C., Brito R.S.C., Armstrong R.A. 2009. Geochronology, Nd isotopes, and reconnaissance geochemistry of volcanic and metavolcanic rocks of the São Luís Craton, northern Brazil: implications for tectonic setting and crustal evolution. Journal of South American Earth Sciences, 27:129-145.
Luna Gold Corporation. Disponível em http://www.lunagold.com/s/ Aurizona.asp. Acessado em 15/06/2011.

Luna Gold Corporation. Disponível em http://www.lunagold.com/en/. Acessado em 24/04/2012

Ohmoto H \& Kerrick D. 1977. Devolatilization equilibria in graphitic systems. American Journal of Science, 277:1013-1044.

Ohmoto H \& Goldhaber M.B. 1997. Sulfur and carbon isotopes. In: Barnes HL (ed.) Geochemistry of hydrothermal ore deposits. New York, Wiley, p. 517-611.

Palheta E.S.M. 2001. Evolução geológica da região nordeste do estado do Pará com base em estudos estruturais e isotópicos de granitoides. Tese de Mestrado, Centro de Geociências, Universidade Federal do Pará, p. 18-29.

Pastana J.M.N. 1995. Programa Levantamentos Geológicos Básicos do Brasil. Programa Grande Carajás. Turiaçú/Pinheiro, folhas AS.23V-D/AS.23-Y-B. Estado do Pará e Maranhão. Brasília, CPRM, 205 p.

Ramboz C., Pichavant M., Weisbrod A. 1982. Fluid immiscibility in natural processes: use and misuse of fluid inclusion data. II. Interpretation of fluid inclusion data in terms of immiscibility. Chemical Geology, 37(1,2):29-48.

Roedder E. 1984. Fluid Inclusions. Mineral Society of America. Reviews in Mineralogy 12, $644 \mathrm{p}$

Ryzhenko B.N \& Volkov V.P. 1971. Fugacity coefficients of some gases in a broad range of temperature and pressures. Geochem Int, 8:468-481.

Seitz J.C \& Pasteris J.D. 1990. Theoretical and practical aspects of differential partitioning of gases by clathrates hydrates in fluid inclusions. Geochimica et Cosmochimica Acta, 54:631-639.

Shepherd T.J., Rankin A.H., Alderton D.H. 1985. A practical guide to fluid inclusion studies. Glasgow, Blackie and Son, 239 p.

Shepherd T.J., Bottrell S.H., Miller M.F. 1991. Fluid inclusion volatiles as an exploration guide to black shale-hosted gold deposits, Dollgelau gold belt, North Wales, UK. Journal of Geochemical Exploration, 42(1):5-24.

Souza S.L.A. 2001. Distribuição do ouro no perfil laterítico do depósito Piaba, Aurizona, Estado do Maranhão. Tese de Doutorado, Universidade Federal do Rio de Janeiro, 161 p.

Arquivo digital disponível on-line no site www.sbgeo.org.br 